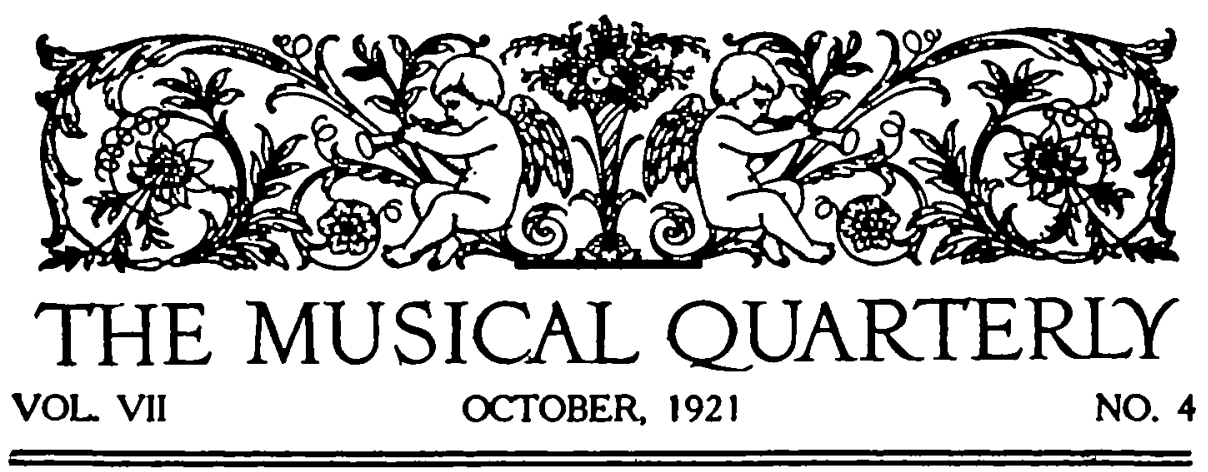

\title{
MUSIC, MELODIOUS AND ODIOUS
}

\section{By CARL ENGEL}

1 would rather be a man of disinterested taste and liberal feeling, to see and acknowledge truth and beauty wherever $I$ found it, than a man of greater and more original genius, to hate, envy and deny all excellence but my own-but that poor scanty pittance of it (compared with the whole) which I had myelf produced!

HasurT-"On Criticism."

$I^{N}$

$\mathrm{N}$ some deep furrow of my brain-where unavowed suspicions slumber open-eyed, until the ripening rays of disillusionment awake them into blind convictions-I harbor the belief that to a multitude of people music has always meant, and will continually mean, but one thing out of two: something melodious or odious. Here is the tonic of your critical scale, and here its higher octave. That listless ears must ever be confounding them, is but the natural result of similarity. Nor am I thinking only of her who defined music as "the breath of God made audible," or of him who pronounced it "the costliest of rackets." As a matter of fact, it would require little dialectic to prove that the most odious and the most melodious music are the same. This much admitted, we might as well confess ourselves deaf, and remain dumb to boot. But that would be cowardice, or a temper so closely resembling it as to rob discretion of its share in valor. It would stunt the noble courage which makes us enter the tilt-yard of criticism, where we face, not possible defeat in even combat, but the inevitable discomfiture of becoming offensive to our acquaintances and absurd to posterity. We are ever assaulting impregnable windmills, or fighting invulnerable phantoms, for the simple reason that the pedal point in all critical debate on music is that droning diapason, melodious-odious; and never can a reasonable majority of ears be expected to agree: which is the higher, which the lower sound? 
Of course, we know this octave spans an infinitude of other ratios; at least, the assumption that it does is the cherished plumb and compass for all intrepid mariners who venture upon the laneless waters of musical arbitrament. But it is nothing unusual to see the sun rising where we expected it to set, because the two polar points of our musical axis, those of melodiousness and odiousness, are so very nearly undistinguishable that each individual sails by a private azimuth of taste. Hence the occasional collisions between opinionated pilots and the general failure to get anywhere. The musical landlubber, being equally "at sea," is by his very uncertainty made all the more determined to proclaim his stand on terra firma, while he is merely crowing lustily into the world his elevation on a slippery and unfirm mixen. The net result of this condition is the variously edifying legacy of musical dicta to which each successive generation falls heir and adds its portion for the enlightenment and the amusement of all the following.

Would it were always as enlightening as it is amusing. Unfortunately, contemporaneous musical criticism is not kept or read long enough after it was written to prove as instructive as it might be. Only the salient blunders are preserved by tradition for the titter of those who are just as prone to guess the wrong way as were their ancestors. One of the distressing effects directly attributable to this calamity, is the fact that so many wary critics, preferring to play safe, stoop to be downright "funny." They hope thus to evade the squibs by quipping. And that is greatly to be regretted. For not the most entertaining article, the cleverest reviling, or the most brilliant persiflage, will be as illuminative as is the honest mind of the contemporary reviewer who detected in Beethoven's Ninth Symphony "the obstreperous roarings of modern frenzy," and who suspected the composer of writing "to suit the present (1824) mania!" At a time when Weber's was still "wild and visionary music" and it could be said that "all the songs in 'Der Freischutz,' with the exception of three, are unvocal," poor Marschner was accused of yielding "to the prevailing passion of the day-noise!" By people of acumen the melodic invention of "that merry manufacturer," Rossini, was called extremely limited; only a few phrases were granted him to be his own, and those he was "repeating on all occasions, whether they relate to the low intrigues of a barber in Spain or to the mighty acts of a prophet in Egypt." Along came Paolo Scudo, who predicted the early and certain fall of "Lohengrin" and "Tannhauuser" because of Liszt's enthusiasm for this music- "ce qui est de très mauvais augure pour l'avenir 
de M. Wagner"-and proclaimed Rossini's "Moise" a work of true genius, asserting that neither Mozart, Gluck nor Weber "n'égale la fécondité et la variété d'accents qui distinguent le compositeur italien!" Who shall blame a music critic after thatand the sampling might be indefinitely prolonged-if he choose to be designedly humorous rather than involuntarily so?

Now, the whole trouble lies in the fact that between melodious and odious there seems to be no secure foot-hold. The truth and the paradox of music is that both extremes constantly meet, that they are ever undergoing an imperceptible fusion and transformation. The two terms do not express a difference in kind, but in degree; and the degree depends on the listener, not on the music. Keener than the joy of hearing music is that of remembering it. Man dearly loves a tune that he can whistle. But let him go on whistling the finest tune for any length of time and he will drop it like hot coal. The ear must become accustomed to, and conscious of, a sound before it can derive from it full esthetic plessure; and with the moment that a sound, or succession of sounds, has been established and accepted, the ear, grown used and overconscious, immediately begins to tire of it.

Jules Combarieu has defined music as "the art of thinking in tones." He must have been not a little impressed with his own definition, since he placed it as a motto at the head of his book on the laws and evolution of music. While it does not embrace all the elements, all the aspects of music any more than do other attempts at concentrating the essence of so volatile a substance, it may serve, if we take into account not only that thought can traverse the whole long range from baseness, through commonplaceness, to sublimity, but also realize that not all of our thoughts must necessarily rise to the surface of consciousness. Our subconscious mind has had to take the blame for a lot of things that we are either too ignorant to comprehend or too ashamed to acknowledge. The pleasure of listening to music is largely a matter of subconscious spheres, in thought or in emotion. Only when the reasons for this pleasure are wholly understood, when music becomes sufficiently articulate to penetrate our consciousness, does the thought "register," as it were, and we have the proud gratification of "following the composer." To lag behind is no worse than to be ahead of him, which is a not infrequent sensation derived from hearing the work of certain men. For if all the arts in common aspire towards the principle of music, all music aspires towards the state of obviousness. We may as well go farther and say that music 
which does not at some time or other reach this state, has not been begot a natural expression of a clear and consequential thought. But what is obvious "before the time" has no claim at all to answer our desire for the mystifying, the exalting tendencies of art, which quench a finer thirst, which fill a higher want, and make of art the noblest form of human satisfaction. Only what has been so conceived that, once become obvious, it resolve greater mystery and unveil deeper truth, may hope to live and to avoid the danger incurred by all things that are too obvious, namely of growing odious. The finest music is perhaps that which persistently evades all efforts of the patient investigator to pluck the petals and pistils apart in majorem Dei gloriam, and yet is manifestly a symbol of cosmic serenity and human perturbation. Take the ludicrous attempt to explain Chopin's Mazurka, Op. 17, No. 4, as portraying the altercation between a Jewish innkeeper and a drunken peasant, earning for it "in Poland"-so 'tis writ-the name of " $Z y d k i$," little Jew! Imagine, a silly pothouse brawl, that vaguest and most concrete bit of Chopin, containing in a few measures the nostalgia of a whole civilization, the subtlest glimpse of personal revealment, exhaling the sweetness of cancer, smilingly kissing the hand of Death, frightful and beautiful like all things tragic and compassioning! God gave the flower perfume, man gave it a Latin name. No, when music is pressed between the leaves of an herbarium, it becomes more ghastly than when organs grind it out in the street, when fiddles scrape it as a seasoning into our food, or when trombone and rattle accompany with it the rites of modern orgiasts.

The most forward, because the most obvious, thing in music is a melodic phrase. Hence it is constantly on the point of becoming odious to someone for whom it has nothing more to resolve, nothing new to unveil. And thus a piece of music will make the wider, the more instant appeal the more obvious it is; and for the same reason it will fall sooner into dislike and oblivion. The so-called "popular" music abounds in pertinent examples. Where are the shows of yesteryear? Greater the pity that such gemlike bibelot as the "Japanese Sandman" must meet the abrupt doom of hackneyed clinquant. But all music, in general, obeys this law. All music that lingers without the threshold, all that has too far overstepped the line of consciousness, is apt to be equally odious to different individuals.

At all times a musical idiom is forming in which some of us read a new melodic message, while to the rest, it remains unintelligible; on the other hand, we are inclined to reject as stale 
an increasingly large number of tunes which by many are still held, or just perceived, to contain the magic of melody. "Both are right in what they admire, both are wrong in condemning the others for what they admire." We might announce the perplexing axiom that melody, "the life of music," is its death-germ. Undoubtedly it is the "melodious" type of music which becomes soonest odious, especially if it tries to be too much of a good thing. Which means that melodies should be picked before they are ripe. The Paris version of the "Bacchanale" still throbs with the communicative pulse of passion and flames with scintillating colors, while the "Evening Star" has paled before the splendor of a richer night and the promise of a fiercer dawn. The sands of time are running nowhere faster than in the realm of tone. Some of the best music is apt to "wear out," and, in the act of wearing, it does not gain enhanced attraction as does an old, familiar suit of clothes. What saves and preserves a great many compositions, is the fact that we hear them so seldom.

For my part, I do not require the emboldening authority of Arthur Schopenhauer to own my unswerving attachment to a good tune. But when Mr. Rachmaninoff presents it to the readers of "The Etude" as bis opinion that the efforts of the poor, benighted Futurists must fail because of "their hatred for anything faintly resembling melody," I instantly climb upon my little dunghill and crow out, with all the vigor and lung power I command, that a few of Mr. Rachmaninoff's prettiest melodies have to my mind already passed into the stage of odiousness, while a good deal of music that is alleged to be tuneless holds me with potent charms. When all is said and done, the essential thing in criticism is the particular perch from which we view art and from which we do our critical crowing. Let the view be a fairly open one, and let our cock-a-doodle-do be possessed of an ingratiating ring, what more can you demand? We shall not quarrel as to what is melodious and what odious, so long as we realize that both terms may be, and are being, applied to the identical music, and that all we require of the critic is to make it attractive and profitable for us to mount with him his beacon, to listen for a "key" note in his call. He must be "the critic as artist." In that capacity, we may well believe that he is a necessity to art, that he is more creative than the artist himself, because "there is no fine art without selfconsciousness, and selfconsciousness and the critical spirit are one." It matters little, therefore, whether we range ourselves on the side of a waning or on that of a crescent phase of art. There are, indeed, different standards of de- 
light, but there is only one pure, strong fire burning with which to search the whole reach of our ken; and we must give a true account of what we see. For, after all, the highest criticism, really, "is the record of one's own soul."

Fate has been often kind to me; its hardest blows have nurtured humbleness and Christian love within my breast. In all concerns with fellow men (and women) I try to be a stoic. Towards music $\dot{I}$ hold incorrigibly skeptic views. The composers for whose works I care, are comparatively few, but they give much to me. That does not mean that I am snobbishly impatient with the rest. My familiarity with the great mass as well as the great masters of music is far from thorough. Thus have $I$ succeeded in remaining unperturbed by the former, and in retaining my respect for the latter. Never having learned to excel on any instrument, I still can go to a piano or violin recital and find the zest of novelty in pieces which other people, exasperated by over-application, look upon as bugbears. Nor is my enjoyment marred by constraining sympathy with struggles overcome. I flee academic fervor and anything soiled with the sweat of drilling. The best of Cicero and Moliere is irretrievably lost to me by school associations.

Encyclopedic knowledge of opus numbers was never given me. My musical horizon is closely bounded. But in that narrow space there are no obstacles to keep me from the sparing stars above. Their light meets me undimmed and warms me with peculiar pleasures. The thing is, not to lose sight of stellar fixedness, while our neighbor sets off, with much ado, his Bengal fires, as shortlived as they are malodorous. Like the moving heavens above, these musical constellations have a very disconcerting way of change. They are subject to frequent shifting - around, perhaps, one or two suns of prime magnitude. New clusters, ever forming, are floating into the field of vision with startling suddenness, only to be eclipsed as suddenly by larger planets. There should be in music, as in astronomy, an open season for shooting stars. Some of them cannot be shot too soon to suit me.

I have not the slightest pretension to think that my case is unparalleled. My experience, surely, is shared by many people, unless they be hidebound: in pigskin, levant or crushed morocco. To all intents it is the same. For the assembling of impressions and beliefs in art, the card index and loose-leaf book are unsurpassed. An occasional rearrangement and weeding-out of cards and leaves is to be recommended. Hence such frank, if otherwise unimportant, avowals as mine have at least the effect 
of a wholesome catharsis on the individual who makes them; sometimes they help others in doing a little house-cleaning among dusty notions of their own. And nothing gathers cobwebs more easily than the inherited ideas which, like the priceless and useless china of grandma, are reverentially placed so high on the shelves of our mental cupboard, that the daily feather-duster of doubting does not reach them. Descartes should have been canonized patron saint of critics. Instead of dissipating doubt, most critics cast lavishly of it before the public. Only the very old and very young enjoy the privilege of being recklessly positive or obstinately negative. For that reason their criticisms are the best reading.

There is nothing more boresome, aside from being well-nigh inconceivable, than an unprejudiced art-critic. Take away from any form of expression the personal note, and you have but an empty blast. What is intolerable is the uninformed critic and the dull. There can hardly be any question that we have too much of the wrong kind of criticism, too little of the right. Here is a pertinent remark penned not in 1921 but in 1789:

With respect to all the feuds and contentions lately occasioned by Music in France, they seem to have annihilated the former disposition of the inhabitants to receive delight from such Music as their country afforded. There are at present certainly too many critics, and too few candid hearers in France as well as elsewhere. I have seen French and German soi-disant connoissours listen to the most exquisite musical performance with the same sans-froid (sic!) as an anstomist attends a dissection. It is all analysis, calculation, and parallel; they are to be wise, not pleased.

And the special bone of contention to which these able surgeons apply their saws, is that ossified dilemma: melodious-odious.

The critic as performer of autopsies does not exactly measure up to Wilde's demands. And yet he should use probe and scalpel, but on himself. That is the "record of one's own soul." Is not in literature, in art the autobiographical the most arresting? And next to ourselves what is there to interest us more than our fellow sufferer? Rousseau's Confessions will outlive "Le Contrat Social" for reasons other than those that put the book on the Index. The pages of musical self-revelation in "Tristan" and "Die Meistersinger" have other qualities to boast of than the exhibitionist tendencies of a "Sinfonia domestica." Music is becoming less and less autobiographical, nor is it getting better for that reason. By the side of the great confessors in music, Bach and Beethoven, stand Franck with his fervent de profundis and the 
maudlin miserere of Tschaikowsky. We have drifted into an era where music, braggartly self-accusing, more often shouts peccavi. But on the whole, ours is reflective music, casting reflections of moods and pictures on the mind. And in this often dazzling play of mirrors the radiation of music has been intensified, while its outline and substance have become diffused. Suggestion has taken the place of statement, and thereby music has learned to say a great many more things than it had ever said before. But again we hear cries of "odious" from those who will not recognize a spade unless you call it by its proper name. Meanwhile the diggers go on with their excavation which becomes the grave of the old and the foundation for the new. Perhaps we are writing music to-day that is too solidly reposing on dead matter. There is nothing deadlier in music than devices. Christopher Simpson, came he to earth again, might find that his opinion of 1667, "concerning our common scale of musick," needed revision. If ten parts in the ultra-modern Schoenberg's compositions are sheer, prophetic genius, forty are helplessness and fifty are vioux jeu, that is, obvious before the time!

And yet real art should never age. It links remote epochs of history into one Spring of high endeavor, and makes of alien races kindreds in the search for beauty. Iet the artist cater to fashion, and his work will die with the birth of another whim. That is the fate of all things which are only timely, that they recede with time. To create is to build new tombs, to sing is to increase the sum of silence. But to create and sing is, nevertheless, the most precious business we can have here below. It is its own reward, and we must do it in the face of certainty that we can only dream those greater treasures, the intangible, elusive masterpieces of the soul: in painting, a shadowy and fragrant landscape, hushed in the strange light of an unfamiliar hour; in sculpture, a vibrantly respondent hand, held but in passing and forever felt; in literature, a page of opulent imagination, robed in the sober elegance of clean and clinging prose, describing nothing of importance save to the heart that languishes; in music, the echo of a cherished voice, the soft, contented laughter of a mistress known and lost in days when sin was too much innocence. Here is true art; more, here is lasting art. For through it all there moves a thread-all art, all life, aspiring towards the principles of music - a thread of living and expressive melody that will not soon grow obvious or odious.

The skeptic turned sentimentalist-fie! What unseemly attitude to strike, what challenge to the giggling crowd! 